\title{
Emotional control and illness acceptance in patients with multiple sclerosis - preliminary findings
}

\author{
Kontrola emocji i akceptacja choroby u pacjentów ze stwardnieniem rozsianym - \\ badanie wstępne
}

Department of Neurology and Stroke, Medical University of Lodz, Łódź, Poland

Klinika Neurologii i Udarów Mózgu, Uniwersytet Medyczny w Łodzi, Łódź, Polska

Correspondence/Adres do korespondencji: Magdalena Obrembska, Klinika Neurologii i Udarów Mózgu, Uniwersytecki Szpital Kliniczny im. Wojskowej Akademii Medycznej Centralny Szpital Weteranów w Łodzi, ul. Żeromskiego 113, 90-549 Łódź, e-mail: sabiniewicz.magdalena@gmail.com

\begin{abstract}
Aim of the study: Mental disorders occur in about $75 \%$ of patients with multiple sclerosis (MS). Examination of the mental state of patients with multiple sclerosis is important for assessing the course of the disease and undertaking appropriate therapeutic interventions. The aim of the study was to assess emotional control and disease acceptance in multiple sclerosis. Methods: 66 people were qualified for the study, including 34 patients with multiple sclerosis and 32 age- and sex-matched controls. Emotional control was assessed using the Courtauld Emotional Control Scale (CECS), and disease acceptance was evaluated using The Acceptance of Illness Scale (AIS). Additionally, a proprietary questionnaire was used to assess auto and allopsychic orientation and to collect demographic data. Results: Stronger suppression of depression and a lower level of disease acceptance were found in the group of patients with multiple sclerosis compared to patients suffering from neurological diseases without organic brain damage. Additionally, patients with multiple sclerosis with higher education achieved results suggesting a higher level of suppression of emotions and suppression of depression than education-matched controls. Patients with multiple sclerosis with secondary and higher education scored significantly higher, which means worse illness acceptance, than those with primary education. Conclusions: Due to the association of emotional suppression with the development of chronic diseases and the level of disease acceptance with adaptation to a chronic health condition, it is recommended to periodically assess these correlates as part of standard psychological examination in patients with multiple sclerosis.
\end{abstract}

Keywords: multiple sclerosis, emotional regulation, emotional adaptation

Streszczenie Cel: Zaburzenia psychiczne występują u około 75\% osób ze stwardnieniem rozsianym. Badanie stanu psychicznego pacjentów ze stwardnieniem rozsianym ma istotne znaczenie dla oceny przebiegu choroby i podejmowania odpowiednich interwencji terapeutycznych. Celem pracy była analiza kontroli emocji i ocena akceptacji choroby w przebiegu stwardnienia rozsianego. Metody: Do badania zakwalifikowano 66 osób, w tym 34 chorych na stwardnienie rozsiane oraz 32 pacjentów z grupy kontrolnej dobranych pod względem wieku i płci do grupy badanej. Ocenę kontroli emocji przeprowadzono przy użyciu skali CECS (Courtauld Emotional Control Scale - Skali Kontroli Emocji), a akceptację choroby zbadano, wykorzystując skalę AIS (Acceptance of Illness Scale - Skalę Akceptacji Choroby). Dodatkowo zastosowano autorską ankietę do oceny orientacji autoi allopsychicznej oraz do zebrania danych demograficznych. Wyniki: W grupie pacjentów ze stwardnieniem rozsianym stwierdzono silniejsze tłumienie depresji oraz niższy poziom akceptacji choroby w porównaniu z pacjentami z innymi chorobami neurologicznymi bez organicznego uszkodzenia mózgu. Dodatkowo pacjenci ze stwardnieniem rozsianym z wyższym wykształceniem osiągali wyniki sugerujące wyższy poziom tłumienia emocji oraz tłumienia depresji niż uczestnicy grupy kontrolnej deklarujący ten sam poziom wykształcenia. Pacjenci ze stwardnieniem rozsianym ze średnim i wyższym wykształceniem osiągali istotnie wyższe wyniki oznaczające gorszą akceptację choroby niż osoby z wykształceniem podstawowym. Wnioski: Ze względu na powiązanie tłumienia emocji z rozwojem chorób przewlekłych oraz poziomu akceptacji choroby z adaptacją do sytuacji choroby przewlekłej zaleca się okresową ocenę tych korelatów w standardowym badaniu psychologicznym pacjentów ze stwardnieniem rozsianym. 


\section{INTRODUCTION}

$\mathrm{M}$ ultiple sclerosis (MS) is a chronic disease characterised by the presence of demyelination foci in the white matter of the brain and spinal cord, leading to impaired nerve conduction and the appearance of designated neurological points (Stelmasiak, 2001). This condition overlaps with mental disorders in up to $75 \%$ of patients (Florkowski et al., 2009). It is estimated that mental disorders often coexist with neurological diseases (Hesdorffer, 2016). Mental disorders such as depression, anxiety disorder, emotional lability, dissociative symptoms and euphoria may be the primary symptom of the disease or the consequence of complications of neurological diseases, as well as the applied pharmacotherapy (Florkowski et al., 2009). It has been shown that the coexistence of mental disorders in MS patients exacerbates neurological disorders (McKay et al., 2018). Quality control of depression and cognitive testing is crucial in maintaining patient's mental health control and these psychological tests as part of the MS treatment program. There are many reports in the literature on the course of depression in MS and data from the standardised mortality ratio (SMR), which show that the risk of suicide in MS patients is twice that in the general population (Kalb et al., 2019; Ribbons et al., 2017). Much less research concerns emotional control in patients with MS. It was already in 1926 that Cottrell and Wilson reported a series of cases showing the relationship between MS and mood disorders, such as depression, euphoria, and emotional control disorders. This aspect is diagnostically important as $10 \%$ of MS patients have symptoms of pseudobulbar affect such as pathological/compulsive laughter or crying disproportionate to the experiences or external factors, and emotional incontinence (Feinstein et al., 1997; Silveira et al., 2019). It has also been observed that emotional lability may occur with exacerbations of MS (Chwastiak and Ehde, 2007). The cerebral background of emotional disturbances in SM is related to the locations of demyelination foci. Lin et al. (2013) suggest that the most severely atrophic brain regions, such as cingulate and frontal cortices of the dominant hemisphere, are correlated with emotional abnormalities and cognitive decline in MS patients. Another study emphasised that atrophy of the left middle frontal gyrus and the right inferior frontal gyrus was selectively related to depression in MS patients (Gobbi et al., 2014). The pseudobulbar affect, which is a manifestation of the loss of control over emotional reactions, is related to the disruption of the cortico-limbic-subcortical-thalamic-pontocerebellar network. This complex neurocircuitry is involved in emotional expression and regulation (King and Reis, 2013). Emotional control is described as monitoring, evaluation and modification of emotions, as well as an ability to influence emotional responses in order to adjust to current needs (Gross, 1998b; Thompson, 1994). Referring to the developmental aspect of this mental function, the process of transition from the primitive forms of emotional control to mature emotional regulation strategies is described, which is associated with the formation of a "strong ego" (Reykowski, 1992). In addition, the two-dimensional nature of affective regulation was emphasised, arguing that emotions are involved in regulating human behaviour and are at the same time controlled by metaregulation mechanisms. The complexity of this issue is reflected in another very important psychological ability, which is the awareness of emotions, which enables the initiation of regulatory strategies (Reykowski, 1992).

Another concept presents this issue in many aspects, describing a group of basic processes of affective regulation, which include mood regulation, coping with stress and defence mechanisms (Gross, 1998a). The theoretical model also distinguishes five forms of regulation: the choice of a stimulus situation, modification of the situation, shift of attention, cognitive change and modulation of the emotional reaction (Górska, 2009). The research indicates that suppressing emotions may lead to their pathological intensification and, consequently, long-term emotional tension and an increased risk of developing chronic diseases, such as peptic ulcer disease or cancer (Janowska and Prystupa, 2012; Olszewski, 2008; Skiba et al., 2018; Wojciechowska and Pawłowski, 2017). When analysing factors that may contribute to cancer, the following are listed: neuroticism and extraversion, as well as suppressing the expression of negative emotions, reacting to loss with a chronic sense of hopelessness/helplessness (Wojciechowska and Pawłowski, 2017). Impaired control of emotions in the form of overly and long-lived negative emotions may result in the development of diseases such as depression, neurosis, abuse of psychoactive substances or eating disorders (Dziemidok et al., 2011; Espeset et al., 2012; Sirois and Burg, 2003). When analysing the literature for studies using the Courtauld Emotional Control Scale (CECS) in MS patients, an interesting research gap is observed. Reports from studies using this scale suggest lower levels of suppression of anger in the group of neurological patients than in patients with other diagnostic categories, and overall emotional control related to age, education and sex of the respondents (Janowski et al., 2014). In addition, the researchers used the Acceptance of Illness Scale (AIS), where it was observed that disease acceptance is negatively correlated with anger suppression (Janowski et al., 2014). Emotional dysregulation contributes to the development of depression and anxiety in the course of MS, which suggests an important role of emotional control in regulating the general mental state of patients (Prakash et al., 2019).

Another important aspect in the course of MS is the acceptance of the illness, which determines adaptation to the situation of a chronic disease. Those who accept their disease experience less negative emotions (Juczyński, 2009). Disease acceptance is a better predictor of quality of life than disability in patients with MS (Dymecka and Gerymski, 2020). Factors such as personality, health behaviours, self-acceptance of the disease, stress coping strategies, and 
the level of social support have a significant impact on the attitude towards a chronic disease (Pietrzykowska et al., 2007). The process of coping with a chronic illness can be compared to the five-step model of grief. The author of this concept, Kübler-Ross (1979), distinguishes between the following phases: shock and denial, anger, bargaining, depression and acceptance. These processes can be compared to the situation of a chronic disease due to the similarity of these phenomena in terms of the loss of something important, as well as the need to activate the ability to change and adapt to new conditions. It has been noticed that the process may be different for each individual, and the length and sequence of the phases may differ (Kübler-Ross, 1979; Stachowska et al., 2013). A high level of disease acceptance and self-esteem was found to reduce anxiety and depression symptoms in MS patients (Kiropoulos et al., 2021).

Patients with impaired insight into the disease present with a lower level of depression than patients with full insight (Gawęda et al., 2008). It is worth emphasising that people with severe cognitive impairment may not show insight into their difficult situation, which undoubtedly affects their emotional functioning (Lewis et al., 2006).

\section{AIM OF THE STUDY}

Our research was aimed at assessing emotional control and illness acceptance in patients with MS compared to patients suffering from neurological diseases without organic brain damage. This paper is an attempt to broaden the knowledge about the diagnosis and control of the affective state of MS patients beyond the scope of the standard procedure.

\section{METHODS}

The study included 34 23-50-year-old patients with MS diagnosed according to the 2010 McDonald criteria and treated with immunomodulatory drugs. The control group included 32 age- and sex-matched patients observed for other neurological disorders, in whom magnetic resonance imaging revealed no central nervous system pathologies. The participants provided their written informed consent to participate in the study and the approval of the Bioethics Committee of the Medical University of Lodz was obtained (No. RNN/201/19/KE).

The demographic characteristics of the MS group are presented in Tab. 1. In both groups, the exclusion criteria included severe general condition, inability to understand commands (failure to complete the survey), refusal to give informed consent to participate in the study, past diagnosis of mental disorders other than anxiety and depressive disorders. Relapse or treatment with corticosteroids over a 3-month period were additional exclusion criteria in the MS group. No patient was excluded from the study due to hearing, vision or motor deficits, which was noted during the study. The study was approved by the local ethics committee.
Before starting the experiment, participants were informed about its purpose and gave informed consent to participate in the study. Both groups were subjected to the same procedure of psychological examination. Additionally, a proprietary questionnaire was used (separate for patients with MS and for people from the control group), which provided demographic data and was used to assess verbal and logical communication skills as well as auto and allopsychic orientation at a level necessary to properly perform the procedure. The questionnaires dedicated to the study group were extended with questions about current immunomodulatory therapy and MS duration. During the procedure, the patients completed the CECS and AIS questionnaires. CECS was created by Watson and Greer, and the Polish adaptation by Juczyński is a tool assessing emotional suppression or expression. The questionnaire includes a general scale and three subscales for anger, depression, and anxiety control. CECS is a self-report tool and it can be used individually or in groups. It contains 21 statements and is intended for both healthy and diseased adults. Questions are answered on a 4-point scale from 1 - "almost never" to 4 - "almost always." The reliability of the scale was assessed by verifying its internal consistency and absolute stability. For this purpose, 60 adults were tested, obtaining Cronbach's alpha coefficients of 0.80 for anger, 0.77 for depression, 0.78 for anxiety and 0.87 for the total emotional control index (Juczyński, 2009).

AIS was created by Felton, Revenson and Hinrichsen and the Polish adaptation was made by Juczyński (2009). It is used to measure the degree of disease acceptance. It contains eight statements describing the negative consequences of poor health, to which the respondent responds on a 5-point scale from 1 - "strongly agree" to 5 - "strongly disagree." The reliability of the tool is determined by the Cronbach's alpha internal consistency index of 0.85 , which was determined in studies involving 138 patients with chronic pain. The study using the AIS scale can be conducted individually or in groups (Juczyński, 2009).

\section{STATISTICAL ANALYSIS}

Statistical analysis was performed using Statistica 13 software. Characteristics of participants including demographical data and psychological assessment were presented as means with standard deviations $(S D)$ or cumulative incidence $(n)$ with percentage in Tab. 1. Distribution of continuous variables was evaluated using the Shapiro-Wilk test. Due to non-parametrical distribution of variables MannWhitney $U$ test was used to compare two groups and Kruskal-Wallis ANOVA to compare more than two groups. Qualitative data was assessed using $\chi^{2}$ test. A univariate and multivariate logistic regression were used to determine whether the results of psychological assessment could differentiate between individuals with and without multiple sclerosis. In the first step, the regression model containing psychometric assessment results as a covariate 


\begin{tabular}{|c|c|c|c|}
\hline Variable & $\begin{array}{c}\text { MS patients } \\
(n=34)\end{array}$ & $\begin{array}{l}\text { Controls } \\
(n=32)\end{array}$ & $p$-value \\
\hline Age $(M, S D)$ & $40.62 \pm 7.35$ & $37.41 \pm 7.46$ & 0.081 \\
\hline \multicolumn{3}{|l|}{ Gender (F, P) } & \multirow{3}{*}{0.852} \\
\hline Female & $22(64.71 \%)$ & $20(62.5 \%)$ & \\
\hline Male & 12 (35.29\%) & $12(37.5 \%)$ & \\
\hline \multicolumn{3}{|l|}{ Marital status (F, P) } & \multirow{3}{*}{0.004} \\
\hline In relationship & $33(97.06 \%)$ & $21(65.63 \%)$ & \\
\hline Single & $1(2.94 \%)$ & $11(34.37 \%)$ & \\
\hline \multicolumn{3}{|c|}{ Education level (F, P) } & \multirow{4}{*}{0.228} \\
\hline Secondary & $20(58.82 \%)$ & $13(40.63 \%)$ & \\
\hline Higher & $10(29.41 \%)$ & $16(50.0 \%)$ & \\
\hline Primary & $4(11.76 \%)$ & $3(9.37 \%)$ & \\
\hline \multicolumn{3}{|l|}{ Employment (F, P) } & \multirow{4}{*}{0.001} \\
\hline Unemployed & $12(35.29 \%)$ & $0(0.0)$ & \\
\hline Physical work & $8(23.53 \%)$ & $14(43.75)$ & \\
\hline Mental work & $14(41.18 \%)$ & $18(56.25)$ & \\
\hline $\begin{array}{l}\text { Anxiolytics and } \\
\text { antidepressant } \\
\text { treatment (F, P) }\end{array}$ & $5(14.71 \%)$ & $2(6.25 \%)$ & 0.265 \\
\hline $\begin{array}{l}\text { Disease duration } \\
(M, S D)\end{array}$ & $8.65 \pm 4.95$ & - & \\
\hline
\end{tabular}

Tab. 1. Demographic data for the study population

was calculated. Covariates having $p \leq 0.2$ were entered into a multivariate model. Multivariate regression was evaluated using Hosmer-Lemeshow test along with goodnessof-fit statistics (Cox-Snell's, Nagelkerke's $R^{2}$ ) with calculation of odds ratios (OR) with 95\% confidence intervals (CI). A $p$ value below 0.05 was considered significant.

\section{RESULTS}

We found significant differences between MS patients and controls in psychological assessment. Detailed results are shown in Tab. 2. In CECS depression scale, MS patients scored significantly higher than controls (18.26 \pm 5.02 vs.

\begin{tabular}{|c|c|c|c|}
\hline Variable & MS patients & Control & $p$-value \\
\hline $\begin{array}{l}\text { CECS } \\
(M, S D)\end{array}$ & $53.44 \pm 14.37$ & $48.13 \pm 12.15$ & 0.064 \\
\hline $\begin{array}{l}\text { Anger } \\
(M, S D)\end{array}$ & $16.24 \pm 6.21$ & $15.28 \pm 4.63$ & 0.629 \\
\hline $\begin{array}{l}\text { Depression } \\
(M, S D)\end{array}$ & $18.26 \pm 5.02$ & $16.28 \pm 5.22$ & 0.041 \\
\hline $\begin{array}{l}\text { Anxiety } \\
(M, S D)\end{array}$ & $18.94 \pm 5.9$ & $17.41 \pm 5.36$ & 0.286 \\
\hline $\begin{array}{l}\text { AIS } \\
(M, S D)\end{array}$ & $25.97 \pm 9.11$ & $32.69 \pm 7.7$ & 0.004 \\
\hline
\end{tabular}

Tab. 2. Psychometric measures in the study population

$16.28 \pm 5.22, \mathrm{p}=0.041$ ), however no significant differences were found in total CECS score and its anger and anxiety inventories between the study groups. In AIS, MS patients scored significantly lower than controls $(25.97 \pm 9.11$ vs. $32.69 \pm 7.7, \mathrm{p}=0.041$ ). No significant relationships were found between psychometric measures and the treatment used (Tab. 3).

Multivariate logistic regression revealed that the AIS score could differentiate between patients with and without MS (OR 1.086, 95\% CI 1.012-1.166), as shown in Tab. 4. Further analysis showed that the total CECS and CECS depression scores were significantly higher in MS patients with higher education than in their control counterparts $(57.90 \pm 12.24$ vs. $45.81 \pm 7.32, \mathrm{p}=0.006,19.50 \pm 4.30$ vs. $15.19 \pm 4.23, \mathrm{p}=0.020$, respectively). It was also found that AIS score was significantly higher in MS patients with secondary and higher education that in individuals with primary education $(27.80 \pm 8.02$ and $27.30 \pm 8.94$ vs. $13.50 \pm 5.45, \mathrm{p}=0.024$, respectively), as shown in Tab. 5 . No such differences were found when comparing secondary or primary education individuals, as shown in Tab. 6 .

\section{DISCUSSION}

The aim of the study was to assess emotional control and disease acceptance in patients with MS. The predominance of women in the study groups results from the selection according to the epidemiological characteristics of MS. It should be taken into account that the selected correlates of mental functioning may depend on gender. Certainly, the small group of MS patients included in the study ( 34 people) is a major limitation of this work.

\begin{tabular}{|l|c|c|c|c|c|}
\hline Variable & Fingolimod $(\boldsymbol{n}=\mathbf{1 1})$ & Glatiramer acetate $(\boldsymbol{n}=\mathbf{7})$ & Interferon $\boldsymbol{\beta}(\boldsymbol{n}=\mathbf{6})$ & Natalizumab $(\boldsymbol{n}=\mathbf{1 0})$ & $\boldsymbol{p}$-value \\
\hline CECS $(M, S D)$ & $57.91 \pm 16.53$ & $44.71 \pm 12.19$ & $56.33 \pm 14.5$ & $52.9 \pm 12.18$ & 0.218 \\
\hline Anger $(M, S D)$ & $19 \pm 6.87$ & $12.43 \pm 3.51$ & $15.67 \pm 6.38$ & $16.2 \pm 6.12$ & 0.181 \\
\hline Depression $(M, S D)$ & $19.09 \pm 5.2$ & $16.43 \pm 3.6$ & $17.83 \pm 7.14$ & $18.9 \pm 4.63$ & 0.543 \\
\hline Anxiety $(M, S D)$ & $19.82 \pm 6.23$ & $15.86 \pm 6.72$ & $22.83 \pm 4.88$ & $17.8 \pm 4.61$ & 0.173 \\
\hline AIS $(M, S D)$ & $23.64 \pm 9.97$ & $25.57 \pm 7.66$ & $30.5 \pm 11.83$ & $26.1 \pm 7.5$ & 0.581 \\
\hline
\end{tabular}

Tab. 3. Psychometric measures in the population of MS patients depending on the disease modifying treatment 


\begin{tabular}{|c|c|c|c|c|}
\hline Variable & OR & OR 95\% Cl & Wald's test & p-value \\
\hline Age & 0.96 & $0.89-1.036$ & 1.096 & 0.295 \\
\hline CECS & 0.967 & $0.927-1.009$ & 2.357 & 0.125 \\
\hline AlS & $\mathbf{1 . 0 8 6}$ & $1.012-1.166$ & 5.277 & $\mathbf{0 . 0 2 2}$ \\
\hline \multicolumn{5}{|l}{ OR - odds ratio; OR 95\% Cl - 95\% Cl-confidence interval. } \\
\hline
\end{tabular}

Tab. 4. Multivariate logistic regression in the study population

However, the results obtained in the preliminary study showed certain trends that may be the basis for future indepth analyses. Due to the insufficient literature on emotional control in MS, we analysed studies in patients with chronic diseases. The global index of emotional control was compared between the samples with different diagnostic categories and found one statistically significant difference between the groups, indicating that neurological patients showed lower emotional control than patients with musculoskeletal diseases (Janowski et al., 2014). This is an important report as our control group consisted of patients with neurological diseases without organic brain damage. Janowski et al. (2014) included, among others, 24 patients with migraine, 4 patients with epilepsy, 3 patients with Parkinson's disease and 1 patient with multiple sclerosis in their study. In our study, patients with MS were separated from the group of patients with neurological diseases to eliminate the influence of organic brain damage on affective functioning. Researchers also reported that patients with other neurological diseases scored lower in the CECS anger subscale than patients with locomotor diseases, urinary condition and diabetes. It was also noted that women suppressed anger statistically significantly more often than male patients, while men were

\begin{tabular}{|c|c|c|c|c|c|}
\hline & & Primary education & Secondary education & Higher education & $p$-value \\
\hline \multirow{5}{*}{ MS patients $(n=34)$} & $\operatorname{CECS}(M, S D)$ & $51.50 \pm 21.14$ & $51.60 \pm 14.23$ & $57.90 \pm 12.24$ & 0.346 \\
\hline & Anger $(M, S D)$ & $17.50 \pm 8.58$ & $15.35 \pm 6.32$ & $17.50 \pm 5.34$ & 0.479 \\
\hline & Depression $(M, S D)$ & $18.00 \pm 7.53$ & $17.70 \pm 5.00$ & $19.50 \pm 4.30$ & 0.522 \\
\hline & Anxiety $(M, S D)$ & $16.00 \pm 7.87$ & $18.55 \pm 6.16$ & $20.90 \pm 4.28$ & 0.325 \\
\hline & $\operatorname{AIS}(M, S D)$ & $13.50 \pm 5.45$ & $27.80 \pm 8.02$ & $27.30 \pm 8.94$ & 0.024 \\
\hline \multirow{5}{*}{ Control $(n=32)$} & $\operatorname{CECS}(M, S D)$ & $46.00 \pm 18.08$ & $51.46 \pm 15.48$ & $45.81 \pm 7.32$ & 0.536 \\
\hline & Anger $(M, S D)$ & $15.00 \pm 5.00$ & $16.31 \pm 5.07$ & $14.50 \pm 4.34$ & 0.700 \\
\hline & Depression $(M, S D)$ & $15.67 \pm 7.23$ & $17.77 \pm 5.93$ & $15.19 \pm 4.23$ & 0.366 \\
\hline & Anxiety $(M, S D)$ & $15.33 \pm 6.66$ & $17.38 \pm 6.38$ & $17.81 \pm 4.46$ & 0.897 \\
\hline & $\operatorname{AIS}(M, S D)$ & $38.00 \pm 2.65$ & $31.38 \pm 8.43$ & $32.75 \pm 7.59$ & 0.581 \\
\hline
\end{tabular}

Tab. 5. Psychometric measures in MS patients and controls depending on the level of education. The ANOVA Kruskal-Wallis test was used to compare the differences between groups

\begin{tabular}{|c|c|c|c|c|}
\hline Education level & Variable & MS patients & Controls & $p$-value \\
\hline \multirow{5}{*}{ Primary } & $\operatorname{CECS}(M, S D)$ & $51.50 \pm 21.14$ & $46.00 \pm 18.08$ & 0.857 \\
\hline & Anger $(M, S D)$ & $17.50 \pm 8.58$ & $15.00 \pm 5.00$ & 0.857 \\
\hline & Depression $(M, S D)$ & $18.00 \pm 7.53$ & $15.67 \pm 7.23$ & 0.857 \\
\hline & Anxiety $(M, S D)$ & $16.00 \pm 7.87$ & $15.33 \pm 6.66$ & 1.000 \\
\hline & $\operatorname{AIS}(M, S D)$ & $13.50 \pm 5.45$ & $38.00 \pm 2.65$ & 0.057 \\
\hline \multirow{5}{*}{ Secondary } & $\operatorname{CECS}(M, S D)$ & $51.60 \pm 14.23$ & $51.46 \pm 15.48$ & 0.957 \\
\hline & Anger $(M, S D)$ & $15.35 \pm 6.32$ & $16.31 \pm 5.07$ & 0.413 \\
\hline & Depression $(M, S D)$ & $17.70 \pm 5.00$ & $17.77 \pm 5.93$ & 0.899 \\
\hline & Anxiety $(M, S D)$ & $18.55 \pm 6.16$ & $17.38 \pm 6.38$ & 0.624 \\
\hline & $\operatorname{AIS}(M, S D)$ & $27.80 \pm 8.02$ & $31.38 \pm 8.43$ & 0.353 \\
\hline \multirow{5}{*}{ Higher } & $\operatorname{CECS}(M, S D)$ & $57.90 \pm 12.24$ & $45.81 \pm 7.32$ & 0.006 \\
\hline & Anger $(M, S D)$ & $17.50 \pm 5.34$ & $14.50 \pm 4.34$ & 0.150 \\
\hline & Depression $(M, S D)$ & $19.50 \pm 4.30$ & $15.19 \pm 4.23$ & 0.020 \\
\hline & Anxiety $(M, S D)$ & $20.90 \pm 4.28$ & $17.81 \pm 4.46$ & 0.150 \\
\hline & $\operatorname{AIS}(M, S D)$ & $27.30 \pm 8.94$ & $32.75 \pm 7.59$ & 0.135 \\
\hline
\end{tabular}

Tab. 6. Comparison of psychometric measures between MS patients and controls depending on the level of education. The Mann-Whitney $U$ test was used to compare the differences between groups 
more likely to suppress anxiety (Janowski et al., 2014). These are interesting findings, taking into account the data from the standardisation studies of the CECS scale, in which no statistically significant differences were found between the sexes (Juczyński, 2009). In our study, these indicators were not compared in terms of gender, as it was concluded that the size of the group and the predominance of women participating in the study would negatively affect the quality of conclusions. However, considering the variety of results, it is worthwhile to conduct studies in future to extend this analysis for gender differences in MS in terms of emotional control.

It was also noted that age was significantly positively correlated with the global index of emotional control, suppression of anger, depression and anxiety, with increasing age associated with greater suppression of anger, depression and anxiety (Janowski et al., 2014). It should be noted that researchers in this work assessed patients aged 18 to 85 years, while in our study we enrolled participants aged 23 to 50 years, which means that a smaller age range was taken into account. In our study it was also observed that MS patients with higher education declared stronger suppression of emotions, including stronger suppression of depression compared to controls. Janowski et al. (2014) observed that subjects with post-secondary education showed lower suppression of emotions than those with lower educational status, mainly those with primary education. The differences in the population of MS patients certainly require indepth research but certainly the above results suggest that when assessing the level of emotional control in a patient, one should take into account their age, level of education and gender, as well as the type of underlying disease. A literature review shows that the issue of emotional control in MS patients is an interesting research gap and requires further analysis to propose specific therapeutic recommendations in this area of mental functioning.

In our study, a lower level of disease acceptance was found in MS patients compared to those with other neurological diseases without organic brain damage. Despite this conclusion, it should be emphasised that the result in the group of MS patients (mean - 25.97, SD - 9.11, $25.97 \pm 9.11$ ) is still higher than the borderline disease acceptance rate obtained by the authors of the test in the study normalisation (mean - 24.81, SD - 7.09) (Sirois and Burg, 2003). Pejas-Grzybek and Skorupska-Król (2015) obtained a mean AIS score of 25.08 for MS patients, which is comparable to the results of our research and observations by Kołtuniuk and Rosińczuk (2021), who obtained a similar mean score (28.3) in the group of patients with MS. Additionally, it was shown that patients who report a higher level of illness acceptance experience fewer side effects associated with the treatments used (Kołtuniuk and Rosińczuk, 2021). This is confirmed by Jankowska-Polańska et al. (2016), who suggests that patients who show a higher degree of illness acceptance experience less treatment-related discomfort and at the same time are more likely to use recommended treatments. Moreover, disease acceptance is a better predictor of the quality of life in patients with MS than disability, and the assessment of adaptation to the disease situation may support the development of comprehensive rehabilitation and support programmes (Dymecka and Gerymski, 2020). Also, illness acceptance is a protective factor for quality of life (QoL) (Van Damme et al., 2016).

\section{CONCLUSIONS}

Our study broadens the diagnostic knowledge in the area of mental state in patients with MS. The conclusions from our research indicate significant differences in emotional suppression and the degree of chronic illness acceptance in the study groups. The following conclusions may be helpful in designing therapeutic interventions for MS patients:

1. MS patients show greater suppression of depression than patients with other neurological diseases without organic brain damage.

2. MS patients show a lower level of disease acceptance than patients with other neurological diseases without organic brain damage.

3. When assessing the suppression of emotions, it is worth taking into account the patient's education as higher levels of emotional suppression and suppression of depression were observed in MS patients with higher education compared to education-matched controls.

4. When assessing illness acceptance, it is worth considering patient's education as MS patients with secondary and higher education obtained scores suggesting worse disease acceptance than those with primary education.

\section{Conflict of interest}

All authors declare that there is no conflict of interest.

\section{References}

Chwastiak LA, Ehde DM: Psychiatric issues in multiple sclerosis. Psychiatr Clin North Am 2007; 30: 803-817.

Cottrell SS, Wilson SAK: Original Papers: The affective symptomatology of disseminated sclerosis: a study of 100 cases. J Neurol Psychopathol 1926; 7: 1-30.

Dymecka J, Gerymski R: [Acceptance of illness as a mediator of the relationship between neurological disability and health-related quality of life of people with multiple sclerosis]. Neuropsychiatr Neuropsychol 2020; 15: 13-20.

Dziemidok P, Makara-Studzińska M, Jarosz MJ: Diabetes and depression: a combination of civilization and life-style diseases is more than simple problem adding - literature review. Ann Agric Environ Med 2011; 18: 318-322.

Espeset EMS, Gulliksen KS, Nordbø RHS et al.: The link between negative emotions and eating disorder behaviour in patients with anorexia nervosa. Eur Eat Disord Rev 2012; 20: 451-460.

Feinstein A, Feinstein K, Gray T et al.: Prevalence and neurobehavioral correlates of pathological laughing and crying in multiple sclerosis. Arch Neurol 1997; 54: 1116-1121.

Florkowski A, Chmielewski H, Gałecki P: Zaburzenia psychiczne w stwardnieniu rozsianym. Aktualn Neurol 2009; 9: 264-266. 
Gawęda $~$, Buciński P, Staniszewski K et al.: Związki wglądu w chorobę, poczucia wpływu na jej przebieg, stylów radzenia sobie z chorobą z objawami psychopatologicznymi w schizofrenii. Psychiatria 2008; 5: 124-133.

Gobbi C, Rocca MA, Riccitelli G et al.: Influence of the topography of brain damage on depression and fatigue in patients with multiple sclerosis. Mult Scler 2014; 20: 192-201.

Górska D: Uogólnione zaburzenie lękowe z perspektywy dysregulacji emocji. Czasopismo Psychologiczne 2009; 15: 105-118.

Gross JJ: Antecedent- and response-focused emotion regulation: divergent consequences for experience, expression, and physiology. J Pers Soc Psychol 1998a; 74: 224-237.

Gross JJ: The emerging field of emotion regulation: an integrative review. Rev Gen Psychol 1998b; 2: 271-299.

Hesdorffer DC: Comorbidity between neurological illness and psychiatric disorders. CNS Spectr 2016; 21: 230-238.

Jankowska-Polańska B, Blicharska K, Uchmanowicz I et al.: The influence of illness acceptance on the adherence to pharmacological and non-pharmacological therapy in patients with hypertension. Eur J Cardiovasc Nurs 2016; 15: 559-568.

Janowska M, Prystupa A: Choroba wrzodowa jako jednostka psychosomatyczna. Med Og Nauk Zdr 2012; 18: 330-333.

Janowski K, Kurpas D, Kusz J et al.: Emotional control, styles of coping with stress and acceptance of illness among patients suffering from chronic somatic diseases. Stress Health 2014; 30: 34-42.

Juczyński Z: Narzędzia pomiaru w promocji i psychologii zdrowia. Pracownia Testów Psychologicznych Polskiego Towarzystwa Psychologicznego, Warszawa 2009.

Kalb R, Feinstein A, Rohrig A et al.: Depression and suicidality in multiple sclerosis: red flags, management strategies, and ethical considerations. Curr Neurol Neurosci Rep 2019; 19: 77.

King RR, Reiss JP: The epidemiology and pathophysiology of pseudobulbar affect and its association with neurodegeneration. Degener Neurol Neuromuscul Dis 2013; 3: 23-31.

Kiropoulos L, Ward N, Rozenblat V: Self-concept, illness acceptance and depressive and anxiety symptoms in people with multiple sclerosis. J Health Psychol 2021; 26: 1197-1206.

Kołtuniuk A, Rosińczuk J: The levels of depression, anxiety, acceptance of illness, and medication adherence in patients with multiple sclerosis - descriptive and correlational study. Int J Med Sci 2021; 18: 216-225.

Kübler-Ross E: Rozmowy o śmierci i umieraniu. Wydawnictwo Media Rodzina, Poznań 1979.

Lewis SW, Barnes TRE, Davies L et al.: Randomized controlled trial of effect of prescription of clozapine versus other second-generation antipsychotic drugs in resistant schizophrenia. Schizophr Bull 2006; 32: 715-723.
Lin A, Chen F, Liu F et al.: Regional gray matter atrophy and neuropsychological problems in relapsing-remitting multiple sclerosis. Neural Regen Res 2013; 8: 1958-1965.

McKay KA, Tremlett H, Fisk JD et al.: Psychiatric comorbidity is associated with disability progression in multiple sclerosis. Neurology 2018; 90: e1316-e1323.

Olszewski J: Wpływ osobowości na choroby i dysfunkcje somatyczne. Wybrane zagadnienia. Ann UMCS Sect J 2008; 21: 113-129.

Pejas-Grzybek L, Skorupska-Król A: Poziom akceptacji choroby w stwardnieniu rozsianym. Pielęgniarstwo Neurologiczne i Neurochirurgiczne 2015; 4: 19-23.

Pietrzykowska E, Zozulińska D, Wierusz-Wysocka B: Jakość życia chorych na cukrzycę. Pol Merkur Lekarski 2007; 23: 311-314.

Prakash RS, Schirda B, Valentine TR et al.: Emotion dysregulation in multiple sclerosis: Impact on symptoms of depression and anxiety. Mult Scler Relat Disord 2019; 36: 101399.

Reykowski J: Procesy emocjonalne, motywacja, osobowość. In: Tomaszewski T (ed.): Psychologia ogólna. Wydawnictwo Naukowe PWN, Warszawa 1992.

Ribbons K, Lea R, Schofield PW et al.: Anxiety levels are independently associated with cognitive performance in an Australian multiple sclerosis patient cohort. J Neuropsychiatry Clin Neurosci 2017; 29: $128-134$.

Silveira C, Guedes R, Maia D et al.: Neuropsychiatric symptoms of multiple sclerosis: state of the art. Psychiatry Investig 2019; 16: 877-888.

Sirois BC, Burg MM: Negative emotion and coronary heart disease. A review. Behav Modif 2003; 27: 83-102.

Skiba M, Duda S, Nowak D et al.: Zachowania zdrowotne a poczucie własnej skuteczności i kontrola emocji u pacjentów z chorobami nowotworowymi. Hygeia Public Health 2018; 53: 363-370.

Stachowska M, Grabowska M, Szewczyczak M et al.: Ocena jakości życia chorych ze stwardnieniem rozsianym. Pielęg Pol 2013; 4: 257-261.

Stelmasiak Z: Praktyczne aspekty stwardnienia rozsianego. Med Rodz 2001; 12: 5-9.

Thompson RA: Emotion regulation: a theme in search of definition. Monogr Soc Res Child Dev 1994; 59: 25-52.

Van Damme S, De Waegeneer A, Debruyne J: Do flexible goal adjustment and acceptance help preserve quality of life in patients with multiple sclerosis? Int J Behav Med 2016; 23: 333-339.

Wojciechowska I, Pawłowski T: Rola osobowości w patogenezie i progresji chorób nowotworowych. Med Rodz 2017; 20: 206-210. 